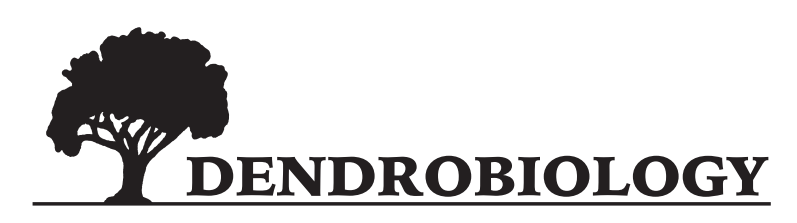

2016, vol. 76, 61-71

http://dx.doi.org/10.12657/denbio.076.006

\author{
Ramunas Vilcinskas, Lina Jociene, Tomas Rekasius, Vitas Marozas, \\ Algimantas Paulauskas, Eugenija Kupcinskiene*
}

\title{
Genetic diversity of Lithuanian populations of Juniperus communis L. in relation to abiotic and biotic factors
}

\author{
Received: 1 February 2016; Accepted: 17 June 2016
}

\begin{abstract}
Juniperus communis L. is increasingly threatened in many parts of Europe, including the Baltic region. Our present study was aimed at evaluation of genetic diversity of $J$. communis populations of Lithuania. Fourteen selected populations differed in geography and habitats (coastal brown dunes covered with natural Scots pine forests, further referred as B; J. communis shrubs, F; transition mires and quaking bogs, D; subcontinental moss Scots pine forests, G; xero-thermophile fringes, E). Molecular variance was analyzed among populations (140 individuals, in total), employing 14 Inter Simple Sequence Repeat (ISSR) markers. Percentage of polymorphic loci differed between populations belonging to the different habitat type, being the highest for population representing habitat F $(68.2 \%)$ and the lowest for populations D $(42.9 \%)$. The data demonstrate the possibility to underestimate or overestimate this parameter if some habitat populations are bypassed. Means per population of Nei's gene diversity and Shannon's information indexes, were 0.158 and 0.239 , respectively. Significant correlation between genetic and geographic distance of populations of J. communis was documented by Mantel test. Bayesian analysis of ISSR data has separated populations of Southern Lithuania from Northern part. Juniperus communis populations representing different habitats showed moderate interpopulation variance at ISSR loci. In ISSR-based dendrograms, individuals were correctly allocated to populations, even in case of populations growing in $0.5 \mathrm{~km}$ vicinity (habitats D and G). Among all populations the most distinct one was representing habitat of $J$. communis shrubs (F) protected by EUNIS. Principal coordinate analysis of weighted averages of Ellenberg's indicator values (EIV) for herbaceous species, separated populations according to habitat type, while the same type analysis of ISSR data allowed distinguishing E habitat populations from populations of all other habitat type but G. Our study shows that on the local (Lithuanian) scale, molecular variance between populations of J. communis at ISSR loci might be related to habitat type. For evaluation and preservation of diversity of $J$. communis, different assessment methods should be included and management strategies should be directed in the way to retain variety of habitats encompassing both widely spread and less common ones.
\end{abstract}

Keywords: ISSR, dominant markers, molecular diversity, juniper, conifers

Addresses: R. Vilcinskas, L. Jociene, A. Paulauskas, E. Kupcinskiene, Department of Biology, Faculty of Nature Sciences, Vytautas Magnus University, Vileikos 8, LT-44404, Kaunas, Lithuania, e-mail: e.kupcinskiene@gmail.com

T. Rekasius, Department of Mathematical Statistics, Gediminas Technical University, Vilnius, Sauletekio al. 11, Vilnius, Lithuania

V. Marozas, Institute of Environment and Ecology, Aleksandras Stulginskis University, Studentu 11, LT5336, Akademija, Kaunas region, Lithuania

*Corresponding author 


\section{Introduction}

Juniperus communis L. (common juniper) has one of the widest distribution areas among plant species (Adams, 2011). Occurring in four continents with its European range spanning from Ireland to Russia and from Spain up to Scandinavia (Thomas et al., 2007), J. communis is threatened in several regions in Europe (Verheyen et al., 2009; Gruwez et al., 2013). It is one out of three conifer species naturally growing in Eastern Baltic States and is important from both ecological and economical points of view (Marozas et al., 2007; Vaitkevičiùtè et al., 2011b; Labokas \& Loziene, 2013). In this region, as documented only within the last 10 years, vitality of $J$. communis has worsened (Vaitkevičiūtè et al., 2011a; 2011b). This might be related to the fact that reproduction decreases with the age and is critical when junipers are over seventy (Ward, 1982).

Molecular studies of Juniperus genera started from isoenzyme analyses and are still ongoing (Oostermeijer \& Knegt, 2004; Boratyński et al., 2009; Hantemirova et al., 2012). Genetic diversity of Juniperus species has been most extensively examined by RAPDs (Adams \& Demeke, 1993; Adams et al., 2003; Adams, 2011; Dzialuk et al., 2011; Kasaian et al., 2011) in comparison to other molecular markers like microsatellites (Provan, 2008; Michalczyk et al., 2006; Douaihy et al., 2011; Sobierajska et al., 2016) or Amplified Fragment Length Polymorphism (Van der Merwe et al., 2000; Rumeu et al., 2011).

Complementary to RAPDs, other dominant markers - Inter Simple Sequence Repeats (ISSRs), are increasingly being used since they have higher specificity (Silva et al., 2011) and are less prone to laboratory conditions (Meloni et al., 2006). Several juniper species growing in Europe from the sect. Juniperus and sect. Caryocedrus, were compared by ISSRs (Adams et al., 2003). A few studies were devoted for evaluation of molecular diversity within juniper species: ISSR markers were applied for $J$. brevifolia (Lima et al., 2010; Silva et al., 2011; Bettencourt et al., 2015) and J. phoenicea populations (Meloni et al., 2006). Prior to our study, the only available information about $J$. communis obtained by RAPD markers came from Scotland (Adams, 2011) and Iran (Kasaian et al., 2011), while ISSR data for this species are still missing.

Molecular diversity of populations of natural Eastern Baltic conifers such as Pinus sylvestris and Picea abies, have been investigated by dominant markers (Zvingila et al., 2002; Areskeviciene et al., 2005; Androsiuk \& Urbaniak, 2014). Up till now, studies on genetic diversity of $J$. communis populations employing ISSRs for Lithuania and other neighboring countries are lacking. In Eastern Baltic area the surveys on this species so far have been focused on ra- dial growth (Vaitkevičiūtè et al., 2011a) and profiles of essential oils (Butkiene et al., 2006; Labokas \& Loziene, 2013).

On the European scale, there are around forty habitats, where J. communis presence is documented (Davies et al., 2004), while on the Baltic States scale this number is lower. In Lithuania the most prevailing habitat type for $J$. communis is subcontinental moss Scots pine forests which are encountered throughout the country. The second most frequent juniper habitat type is xero-thermophile fringes populations, which are mainly situated in the Central and Southern parts of Lithuania. Areas of Juniperus communis shrubs and coastal brown dunes covered with natural Scots pine forests in Lithuania are very small, while transition mires and quaking bogs are very atypical and rare junipers habitats in the country.

Analysis of genetic diversity is crucial source of information about the state of juniper populations in Lithuania, prompting the best measures for selection and other landscape management programs. Our present study was aimed at evaluation of genetic diversity at ISSR loci of J. communis populations in Lithuania with particular emphasis on habitat type. To our best knowledge, this is the first study that investigates the genetic structure of this part of species range in relation to habitat type.

\section{Materials and Methods}

\section{Study sites}

Fourteen locations of Juniperus communis L. were selected in the way to represent different habitats and to cover all the territory of Lithuania. Location of most populations and their habitat type was well known from the former dendrological and biochemical research (Vaitkevičiūtè et al., 2011a; 2011b; Labokas \& Loziene, 2013). Populations were entitled according to location (the number) and habitat type (the first letter of the habitat code, following classification of Davies et al., 2004; Table 1). Geographic distances between sites ranged from 46 to $339 \mathrm{~km}$. In addition to the scattered through the country populations, two couples of neighboring ( $0.5 \mathrm{~km}$ distance) populations ( $3 \mathrm{D}-4 \mathrm{G}$ and $7 \mathrm{G}-8 \mathrm{D}$ ) representing distinct habitats were included. To relate molecular data with climate, meteorological data of 2010-2015 year (Table 1) were taken from the stations closest to the sampling sites. Sampling was carried out in the $3^{\text {rd }}$ decade of June, 2012. Inside each population juniper shoots were taken from the middle part of the crown from 10 female plants growing at least 10 meters apart from each other (Gruwez et al., 2013). J. communis is dioecious species, to make material as adequate as possible, only one sex plants were col- 
Table 1. Geography, meteorological data (mean for 2010-2015) and habitat types of Lithuanian populations of J. communis

\begin{tabular}{cccccccccc}
\hline $\begin{array}{c}\text { Abbreviated } \\
\text { population } \\
\text { name }\end{array}$ & $\begin{array}{c}\text { Location* of } \\
\text { population }\end{array}$ & $\begin{array}{c}\text { Habitat } \\
\text { code** }\end{array}$ & $\begin{array}{c}\text { Latitude } \\
(\mathrm{N})\end{array}$ & $\begin{array}{c}\text { Longitude } \\
(\mathrm{E})\end{array}$ & $\begin{array}{c}\text { Altitude } \\
(\mathrm{m})\end{array}$ & $\begin{array}{c}\text { Annual } \\
\text { mean T } \\
\left({ }^{\circ} \mathrm{C}\right)\end{array}$ & $\begin{array}{c}\text { Mean T }\left({ }^{\circ} \mathrm{C}\right) \\
\text { of vegetation } \\
\text { period }\end{array}$ & $\begin{array}{c}\text { Annual } \\
\text { rainfall } \\
(\mathrm{mm})\end{array}$ & $\begin{array}{c}\text { Rainfall of } \\
\text { vegetation } \\
\text { period }(\mathrm{mm})\end{array}$ \\
\hline 1 B & Neringa & $\mathrm{B} 1.71$ & $55^{\circ} 30^{\prime}$ & $21^{\circ} 06^{\prime}$ & 25 & 8.8 & 14.0 & 790 & 476 \\
2 F & Skuodas & $\mathrm{F} 3.16$ & $56^{\circ} 07^{\prime}$ & $21^{\circ} 35^{\prime}$ & 51 & 7.6 & 12.8 & 835 & 502 \\
3 D & Kelme D & $\mathrm{D} 2.3$ & $55^{\circ} 46^{\prime}$ & $22^{\circ} 58^{\prime}$ & 148 & 7.7 & 13.2 & 658 & 435 \\
4 G & Kelme G & $\mathrm{G} 3.42111$ & $55^{\circ} 46^{\prime}$ & $22^{\circ} 58^{\prime}$ & 148 & 7.7 & 13.2 & 658 & 435 \\
5 G & Panevezys & $\mathrm{G} 3.42111$ & $55^{\circ} 51^{\prime}$ & $24^{\circ} 40^{\prime}$ & 65 & 7.8 & 13.4 & 632 & 419 \\
6 G & Rokiskis & $\mathrm{G} 3.42111$ & $56^{\circ} 05^{\prime}$ & $25^{\circ} 17^{\prime}$ & 78 & 7.7 & 13.3 & 708 & 457 \\
7 G & Ignalina G & $\mathrm{G} 3.42111$ & $55^{\circ} 23^{\prime}$ & $26^{\circ} 03^{\prime}$ & 145 & 7.2 & 13.0 & 674 & 438 \\
8 D & Ignalina D & $\mathrm{D} 2.3$ & $55^{\circ} 23^{\prime}$ & $26^{\circ} 03^{\prime}$ & 145 & 7.2 & 13.0 & 674 & 438 \\
9 E & Kaunas & $\mathrm{E} 5.21$ & $54^{\circ} 48^{\prime}$ & $24^{\circ} 10^{\prime}$ & 81 & 8.1 & 13.6 & 697 & 485 \\
$10 \mathrm{E}$ & Jurbarkas & $\mathrm{E} 5.21$ & $55^{\circ} 08^{\prime}$ & $23^{\circ} 27^{\prime}$ & 70 & 7.5 & 12.9 & 679 & 426 \\
$11 \mathrm{E}$ & Kalvarija & $\mathrm{E} 5.21$ & $54^{\circ} 15^{\prime}$ & $23^{\circ} 17^{\prime}$ & 161 & 7.9 & 13.4 & 708 & 477 \\
$12 \mathrm{G}$ & Alytus & $\mathrm{G} 3.42111$ & $54^{\circ} 09^{\prime}$ & $24^{\circ} 12^{\prime}$ & 112 & 7.7 & 13.2 & 743 & 490 \\
$13 \mathrm{E}$ & Trakai & $\mathrm{E} 5.21$ & $54^{\circ} 30^{\prime}$ & $24^{\circ} 42^{\prime}$ & 155 & 7.7 & 13.2 & 743 & 490 \\
$14 \mathrm{G}$ & Salcininkai & $\mathrm{G} 3.42111$ & $54^{\circ} 11^{\prime}$ & $25^{\circ} 42^{\prime}$ & 187 & 7.7 & 13.2 & 743 & 490 \\
Mean & & & & & 112 & 7.7 & 13.3 & 710 & 461 \\
\hline
\end{tabular}

*location is provided in the Fig. 4 ; ${ }^{* *}$ code, corresponding habitat type: B1.71 - coastal brown dunes covered with natural Scots pine forests, F3.16 - Juniperus communis shrubs, D2.3 - transition mires and quaking bogs, G3.42111 - subcontinental moss Scots pine forests, E5.21 - xero-thermophile fringes.

lected. For medicinal and other economic purposes juniper seeds are the most often used, that is why female individuals, 140 in total were sampled for DNA analyzes.

In order to relate molecular data with habitat types, at each site herbaceous species composition was recorded and abundance of each species was evaluated by percentage cover. The values of the environment (light, temperature, continentality, soil moisture, reaction and nitrogen) at the sites were estimated, using species indicator values (Ellenberg et al., 1991) in proportion to species percentage cover (present at the site), using weighted average method (Jongman et al., 1995) and summarizing separate factor data by principal component analysis.

\section{DNA extraction, PCR and ISSR analysis}

Total genomic DNA was isolated using modified CTAB method (Doyle \& Doyle, 1990), with details followed that of Areskeviciene et al. (2005). Current-year needles $(0.5-1.0 \mathrm{mg})$ detached from each individual were ground in the liquid nitrogen and transferred to $1 \mathrm{ml}$ extraction buffer which was prepared following proportions: $0.4 \mathrm{ml} 0.5 \mathrm{M}$ EDTA, 1 $\mathrm{ml} 1 \mathrm{M}(\mathrm{pH}=8.0)$ TRIS (Amresco, USA), $2.75 \mathrm{ml}$ $5 \mathrm{M} \mathrm{NaCl}, 2 \mathrm{ml}$ (1\%) CTAB (Carl Roth GmbH+Co. KG, Germany), $0.02 \mathrm{ml} \beta$-mercaptoethanol (BME, Carl Roth $\mathrm{GmbH}+$ Co.KG, Germany), 10 mg polyvinylpyrrolidone-30 (PVP-30; Carl Roth GmbH+Co. KG, Germany), $1.83 \mathrm{ml}$ distilled water. Other details of DNA extraction corresponded to the method cited above. The quantity and quality of DNA was assessed by electrophoresis in $1.5 \%$ agarose gel and by
NanoDrop spectrophotometer (Thermo Fisher Scientific, USA).

The ISSR markers were selected following Adams et al. (2003). For ISSRs assessment 15 oligonucleotid primers were tested and later on 14 were used for the final population analyses (Table 2). The polymerase chain reaction (PCR) was carried out in 15 $\mu \mathrm{l}$ volume containing $20 \mathrm{ng}$ of genomic DNA, 0.6 unit of recombinant Taq DNA polymerase (Thermo Fisher Scientific, Lithuania), $1.5 \mu \mathrm{l} 10 \mathrm{X}$ Taq reaction buffer $\left(750 \mathrm{mM}\right.$ Tris- $\mathrm{HCl}\left(\mathrm{pH} 8.8\right.$ at $\left.25^{\circ} \mathrm{C}\right), 200 \mathrm{mM}$ $\left(\mathrm{NH}_{4}\right)_{2} \mathrm{SO}_{4} ; 0.1$ (v/v) Tween 20$), 1.2 \mathrm{mM} \mathrm{MgCl}, 0.2$ $\mathrm{mM}$ of each dNTPs, $0.36 \mu \mathrm{M}$ primer (Metabion International AG, Germany) and 15 ng BSA. The ISSRPCR was performed with a PeqStar Thermocycler (Peqlab, Germany). Following PCR steps included: initial denaturation at $94{ }^{\circ} \mathrm{C}(1.5 \mathrm{~min})$ followed by 40 cycles of denaturation at $91^{\circ} \mathrm{C}(1 \mathrm{~min})$, annealing at $53{ }^{\circ} \mathrm{C}(2 \mathrm{~min})$, extension at $72{ }^{\circ} \mathrm{C}(2 \mathrm{~min})$, and with two additional steps for final extension at $50{ }^{\circ} \mathrm{C}(2 \mathrm{~min})$ and $72{ }^{\circ} \mathrm{C}(5 \mathrm{~min})$. We could obtain PCR reaction only after increasing primer annealing temperature up to $53{ }^{\circ} \mathrm{C}$, which is higher than $50{ }^{\circ} \mathrm{C}$ that was used in the study cited above. PCR products were separated by electrophoresis on $1.5 \%$ agarose gel run $(120 \mathrm{~min})$ at $5 \mathrm{~V} / \mathrm{cm}$ in $1 \mathrm{X}$ TBE buffer, stained with ethidium bromide. Photographs were taken under UV light using GelDoc-It2 Imager (UVP, USA). All samples were analyzed at least twice in separate PCR runs. Selected samples from the former analyses as a size reproducibility measure were included into subsequent PCR set with new individuals. The size of DNA fragments was estimated according to gene ruler (Gene Ruler ${ }^{\mathrm{TM}} 100$ bp Plus DNA Ladder). 
Table 2. Size and number of J. communis DNA fragments generated by individual ISSR primer per population and characteristics of the primers

\begin{tabular}{ccccc}
\hline $\begin{array}{c}\text { Name of the } \\
\text { primer }\end{array}$ & $\begin{array}{c}\text { Sequence of the primer } \\
5^{\prime} \rightarrow 3^{\prime}\end{array}$ & $\begin{array}{c}\text { Size of DNA } \\
\text { fragments bp }\end{array}$ & $\begin{array}{c}\text { Total number of DNA fragments } \\
\text { per primer }\end{array}$ & $\begin{array}{c}\text { DNA fragment numbers per } \\
\text { population }^{* *}\end{array}$ \\
\hline 807 & $(\mathrm{AG})_{8} \mathrm{~T}$ & $200-1900$ & 20 & $9.15 \pm 0.36$ \\
808 & $(\mathrm{AG})_{8} \mathrm{C}$ & $280-2800$ & 24 & $10.4 \pm 0.48$ \\
811 & $(\mathrm{GA})_{8} \mathrm{C}$ & $200-2500$ & 24 & $9.57 \pm 0.55$ \\
812 & $(\mathrm{GA})_{8} \mathrm{~A}$ & $200-1800$ & 25 & $18.2 \pm 0.59$ \\
818 & $(\mathrm{CA})_{8} \mathrm{G}$ & $250-2200$ & 18 & $6.51 \pm 0.32$ \\
823 & $(\mathrm{TC})_{8} \mathrm{C}$ & $250-2500$ & 25 & $9.82 \pm 0.49$ \\
824 & $(\mathrm{TC})_{8} \mathrm{G}$ & $280-2500$ & 24 & $7.84 \pm 0.48$ \\
825 & $(\mathrm{AC})_{8} \mathrm{~T}$ & $450-2100$ & 17 & $6.47 \pm 0.38$ \\
835 & $(\mathrm{AG})_{8} \mathrm{YC}$ & $220-2900$ & 23 & $12.1 \pm 0.51$ \\
836 & $(\mathrm{AG})_{8} \mathrm{YA}$ & $150-1800$ & 20 & $7.53 \pm 0.33$ \\
846 & $(\mathrm{CA})_{8} \mathrm{RT}$ & $220-2800$ & 29 & $10.6 \pm 0.54$ \\
847 & $(\mathrm{CA})_{8} \mathrm{RC}$ & $300-2500$ & 23 & $6.11 \pm 0.34$ \\
857 & $(\mathrm{AC})_{8} \mathrm{YG}$ & $210-2500$ & 30 & $8.79 \pm 0.51$ \\
858 & $(\mathrm{TG})_{8} \mathrm{RT}$ & $400-2200$ & 19 & $5.94 \pm 0.38$ \\
\hline
\end{tabular}

"R, Y - positions for several possible bases. $\mathrm{R}-\mathrm{A}$ or $\mathrm{G} ; \mathrm{Y}-\mathrm{C}$ or $\mathrm{T}$ " mean $\pm \mathrm{CI}-$ Confidence Interval; $\mathrm{n}=14, P \leq 0.05$.

\section{Statistical analysis}

The amplified DNA fragments were treated as dominant markers and regardless of their intensities (Sanchez-Gomez et al., 2013) scored as presence (' 1 ') and absence (' 0 '). Molecular diversity parameters within populations, genetic differentiation $\left(G_{\mathrm{ST}}\right)$ and $G_{\mathrm{ST}}$-derived gene flow $\left(N_{\mathrm{m}}\right)$ were calculated using PopGene v. 1.31 (Yeh et al., 1999). Populations were compared according to Nei's unbiased genetic distances (GD; Nei, 1978). To estimate variance components partitioned within populations and among populations AMOVA in Arlequin v. 3.1 (Excoffier \& Lischer, 2010) was performed. In addition, hierarchic AMOVA was carried out grouping populations according to their geographic region or habitat type. Significance of correlations between genetic and geographic distances (Mantel test) and principal coordinate analysis (PCoA) were done in GENALEX program, v. 6.5 (Peakall $\&$ Smouse, 2012). Dendrogram of genetic relationships among individuals of populations was constructed by TREECON program v. 1.3 (Van De Peer \& De Wachter, 1994). A Bayesian cluster analysis was performed using admixture ancestry model within STRUCTURE v. 2.3.3 (Pritchard et al., 2000; Falush et al., 2003). Probable number of population clusters $(K)$ was set from 1 to 14 . $K$-values were simulated across 20 replicate runs of 1000000 iterations after a burn-in period of 100000 . The $\Delta K$ method of Evanno et al. (2005) was used. Percentage of polymorphic DNA fragments in populations was compared to altitude and climate data calculating Pearson's correlations by STATISTICA v. 7.0 (StatSoft Inc., USA, 2004).

\section{Results}

Average indicator values of herbaceous species in proportion to species percentage cover have revealed the following characters of $J$. communis sites: ranges of the minimum and maximum values were as follows, light - 5.70-7.31 (populations $7 \mathrm{G}-11 \mathrm{E}$ ), temperature $-3.00-5.82(1 \mathrm{~B}-10 \mathrm{E})$, continentality $-3.71-$ 5.26 (11 E - $3 \mathrm{D})$, soil moisture - 4.18-7.79 (6 G - 3 $\mathrm{D})$, soil reaction $-2.71-7.40$ (1 B - 11 E), soil nitrogen - 2.18-4.39 (6 G - 13 E). Principal component analysis performed on these values for each site (Fig. 1) separated populations into three main clusters: one cluster, comprising populations $9 \mathrm{E}, 10 \mathrm{E}, 11 \mathrm{E}, 13$ $\mathrm{E}$, the second cluster, comprising populations $3 \mathrm{D}, 8$ $\mathrm{D}$ and the third cluster, comprising eight populations 1 B, 2 F and 4 G, 5 G, 6 G, 7 G, 12 G, 13 G populations.

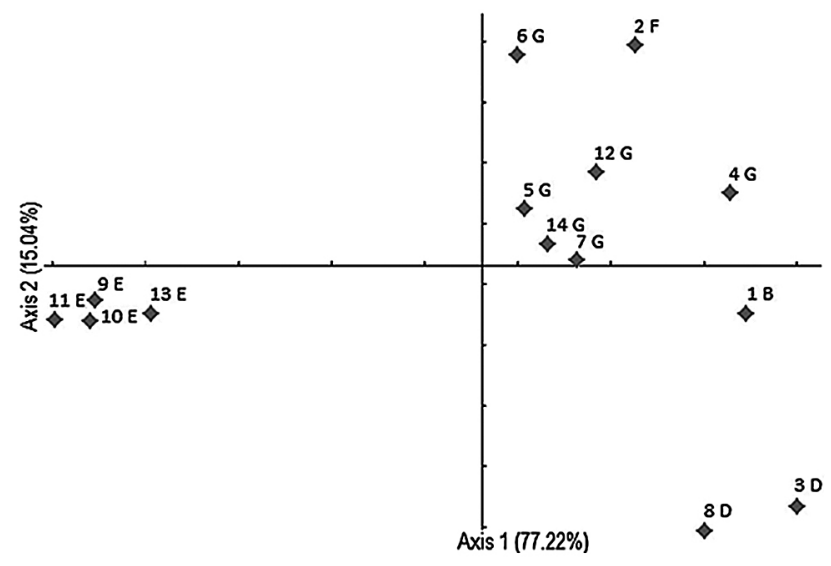

Fig. 1. Principal coordinate analyses of Ellenberg light, temperature, continentality, soil moisture, reaction and nitrogen values for each site. Average EIV of neighbouring herbaceous species in proportion to species percentage cover were plotted for each site 
Table 3. Genetic diversity parameters (mean \pm confidence interval) of Lithuanian populations of $J$. communis (\% P - percentage of polymorphic DNA loci; $h$ - index of Nei's gene diversity; $I$ - Shannon's information index) based on ISSR data

\begin{tabular}{ccccc}
\hline Population $^{*}$ & Number of polymorphic DNA loci & $\% \mathrm{P}$ & $h$ & $I$ \\
\hline 1 B & 154 & 48.0 & $0.175 \pm 0.021$ & $0.262 \pm 0.031$ \\
2 F & 219 & 68.2 & $0.225 \pm 0.020$ & $0.343 \pm 0.029$ \\
3 D & 137 & 42.7 & $0.140 \pm 0.020$ & $0.213 \pm 0.029$ \\
8 D & 138 & 43.0 & $0.144 \pm 0.020$ & $0.218 \pm 0.030$ \\
\hline Mean for D & 138 & 42.9 & $0.144 \pm 0.020$ & $0.215 \pm 0.030$ \\
\hline 4 G & 152 & 47.4 & $0.155 \pm 0.020$ & $0.237 \pm 0.029$ \\
5 G & 130 & 40.5 & $0.140 \pm 0.020$ & $0.212 \pm 0.030$ \\
6 G & 122 & 38.0 & $0.119 \pm 0.019$ & $0.183 \pm 0.028$ \\
7 G & 160 & 49.8 & $0.175 \pm 0.021$ & $0.263 \pm 0.031$ \\
$12 \mathrm{G}$ & 157 & 48.9 & $0.158 \pm 0.020$ & $0.241 \pm 0.029$ \\
$14 \mathrm{G}$ & 124 & 38.6 & $0.125 \pm 0.019$ & $0.192 \pm 0.028$ \\
\hline Mean for G & 141 & 43.9 & $0.145 \pm 0.020$ & $0.221 \pm 0.029$ \\
\hline 9 E & 144 & 44.9 & $0.152 \pm 0.021$ & $0.230 \pm 0.030$ \\
$10 \mathrm{E}$ & 175 & 54.5 & $0.183 \pm 0.021$ & $0.277 \pm 0.030$ \\
$11 \mathrm{E}$ & 155 & 48.3 & $0.155 \pm 0.020$ & $0.238 \pm 0.029$ \\
$13 \mathrm{E}$ & 149 & 46.4 & $0.161 \pm 0.021$ & $0.243 \pm 0.030$ \\
\hline Mean for E & 156 & 48.5 & $0.163 \pm 0.021$ & $0.247 \pm 0.030$ \\
Mean & 151 & 47.1 & $0.158 \pm 0.020$ & $0.239 \pm 0.030$ \\
\hline
\end{tabular}

"location of population and habitat code are provided in the Table 1.

In our study the number of DNA fragments generated by separate ISSR primers ranged between 17 (by primer 825) and 30 (by primer 857), with a mean of 22.9. As an average 9.2 fragments were generated per primer per population. For all individuals the total number of the fragments was 321 (Table 2). At the species level all DNA fragments were polymorphic. The number of polymorphic fragments per population ranged between 122 (for $6 \mathrm{G}$ population; Table 3) and 219 (for $2 \mathrm{~F}$ population). Among $14 \mathrm{popu}$ lations the percentage of polymorphism ranged between 38.0 and 68.2, mean being 47.1. Inter Simple Sequence Repeat loci related polymorphism of populations belonging to distinct habitat type was the lowest for D and $G$ habitats, intermediate - for B and $\mathrm{E}$ habitats and the highest for $\mathrm{F}$ habitat. For the indexes of Nei's gene diversity and Shannon's information, means per population were 0.158 and 0.239 , respectively, with minimum and maximum values ranging in the intervals, $0.119-0.225$ and $0.183-$ 0.343 . According to the indexes of Nei's gene diversity and Shannon's information the most contrasting populations were also from different habitats.

AMOVA showed that genetic diversity among populations was $44.1 \%$, and among individuals within populations it amounted to $55.9 \%$. Nei's (1978) genetic distances (GDxy) between populations ranged in the interval $0.139-0.317$, mean of genetic distances for all pairs of populations was 0.217 . For paired populations (growing in $0.5 \mathrm{~km}$ distance to each other) genetic distances were minimal (0.139 between $7 \mathrm{G}$ and $8 \mathrm{D}$ populations and 0.144 between $3 \mathrm{D}$ and $4 \mathrm{G}$ populations). In the dendrogram ob- tained from ISSR data for individuals, all the plants were correctly allocated to their sampling sites (Fig. 2). The dendrogram consisted of two main branches, one of them (I) represented individuals from the population $2 \mathrm{~F}$. The second branch was split into two $2^{\text {nd }}$ order branches: II-1 consisted of individuals from two populations (13 E and $14 \mathrm{G}$ ), II-2 contained remaining (11) populations very distinct in geography (representing all locations of Lithuania - East and West, South and North) and habitats (representing four habitat types - B, D, E, G).

Principal coordinate analysis of ISSR data (Fig. 3) revealed importance of the first three axes which described respectively $16.59 \%, 11.86 \%$ and $11.15 \%$ (sum being $39.6 \%$ ) of the total genetic diversity of populations. In the two-dimensional plot of the PCoA ( $1^{\text {st }}$ and $2^{\text {nd }}$ variable axes) there were two big groups of populations: the $1^{\text {st }}$ group was formed by 8 populations ( $1 \mathrm{~F}, 2 \mathrm{~B}, 3 \mathrm{D}, 4 \mathrm{G}, 5 \mathrm{G}, 6 \mathrm{G}, 7 \mathrm{G}$ and 8 D) and the other group encompassed 6 populations (9 E, 10 E, 11 E, 12 G, 13 E and $14 \mathrm{G}$ ).

Among Lithuanian populations of $J$. communis mean value of Nei's coefficient of genetic differentiation $\left(G_{S T}\right)$ was 0.491 and the mean value of gene flow $\left(N_{\mathrm{m}}\right)$ was 0.518 . Bayessian analysis of ISSRs data (Fig. 4) has suggested the presence of either 7 clusters (the highest $\Delta K$ value) or 2 clusters (with the next, very close to the highest $\Delta K$ ). Most genes of populations 1 F, 2 B, 3 D, 4 G, 5 G and 6 G belonged to the first cluster and genes of the populations $9 \mathrm{E}$, $10 \mathrm{E}, 11 \mathrm{E}, 12 \mathrm{G}, 13 \mathrm{E}$ and $14 \mathrm{G}$ mainly belonged to the second cluster. Two populations (7 G and $8 \mathrm{D}$ ) contained meaning parts of both cluster genes. 

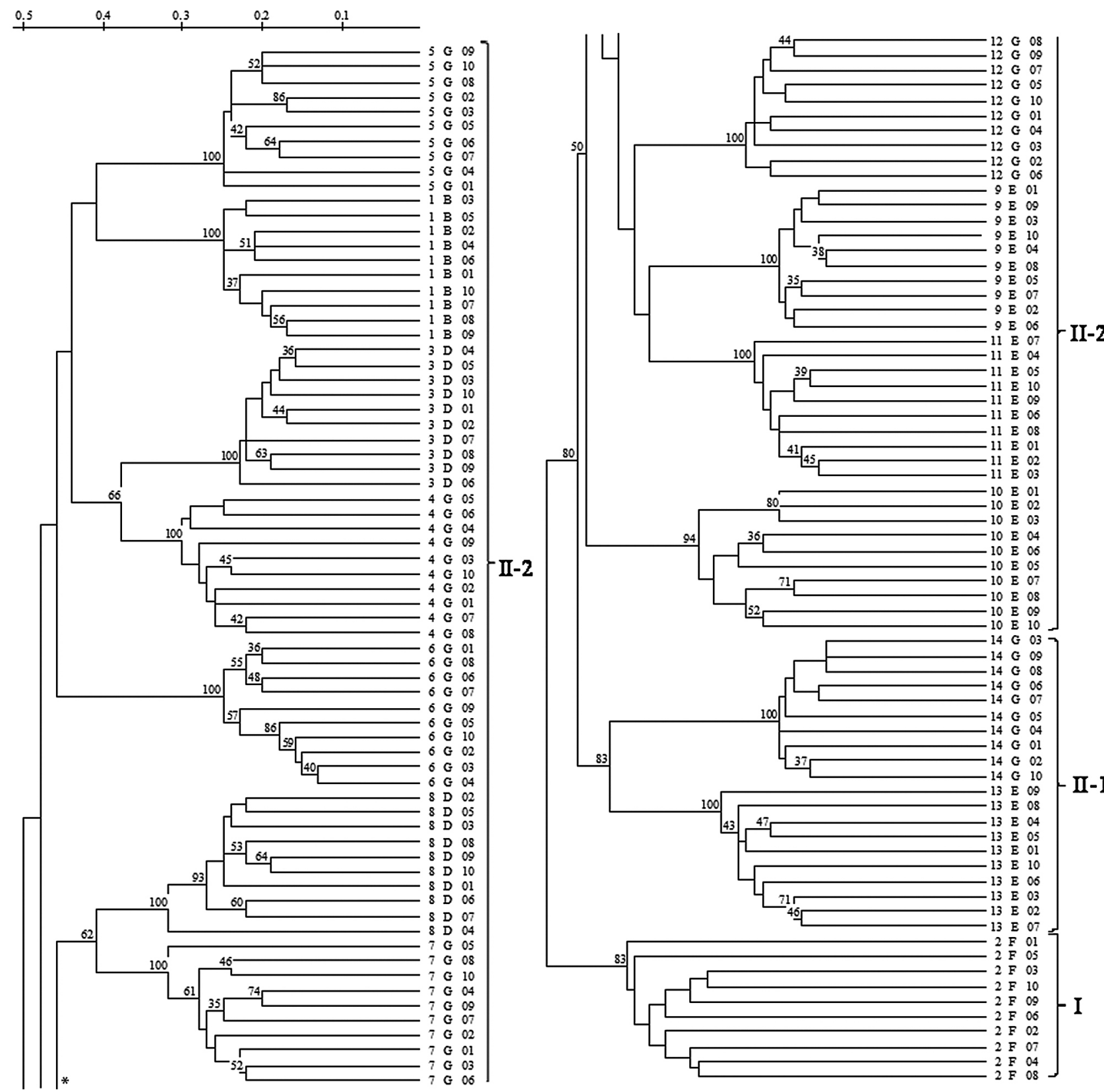

Fig. 2. Dendrogram of genetic relationships among 140 individuals of J. communis based on 14 ISSR markers using UPGMA algorithm and the genetic distances which are shown on the top; bootstrap values are obtained after 1000 iterations (the numbers at each node indicate bootstrap values above $30 \%$ ), * brake

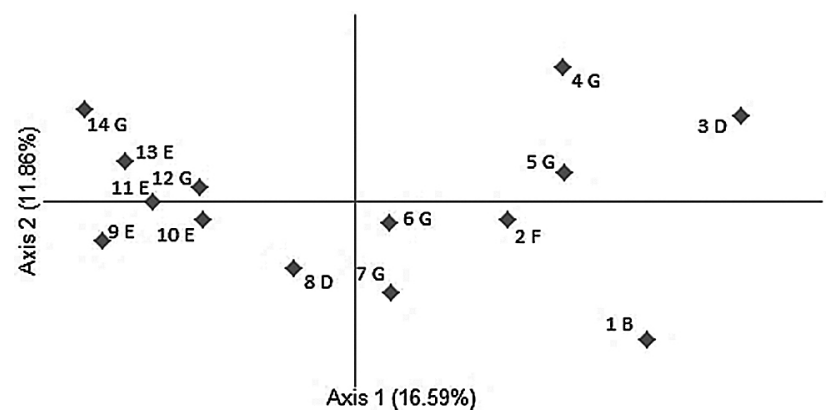

Fig. 3. Principal coordinate (PC 1 vs. PC 2) analysis of ISSR data of 14 Lithuanian populations of $J$. communis
Mantel test showed significant $(\mathrm{p}<0.01)$ correlations $(r=0.503)$ between genetic and geographic distances of populations of $J$. communis. Correlations between population molecular parameters and climate parameters (listed in the Table 1) or altitude, were not significant. For hierarchic AMOVA (Table 4) populations were subdivided into 2 groups: northern (NLT) and southern parts (SLT), as it was prompted by principal coordinate analyses (Fig. 3). In case of such grouping, $6.2 \%$ of molecular variance was significantly related to differences between these parts of Lithuania. Populations were also subdivided according to the habitat type into: a) 5 groups repre- 

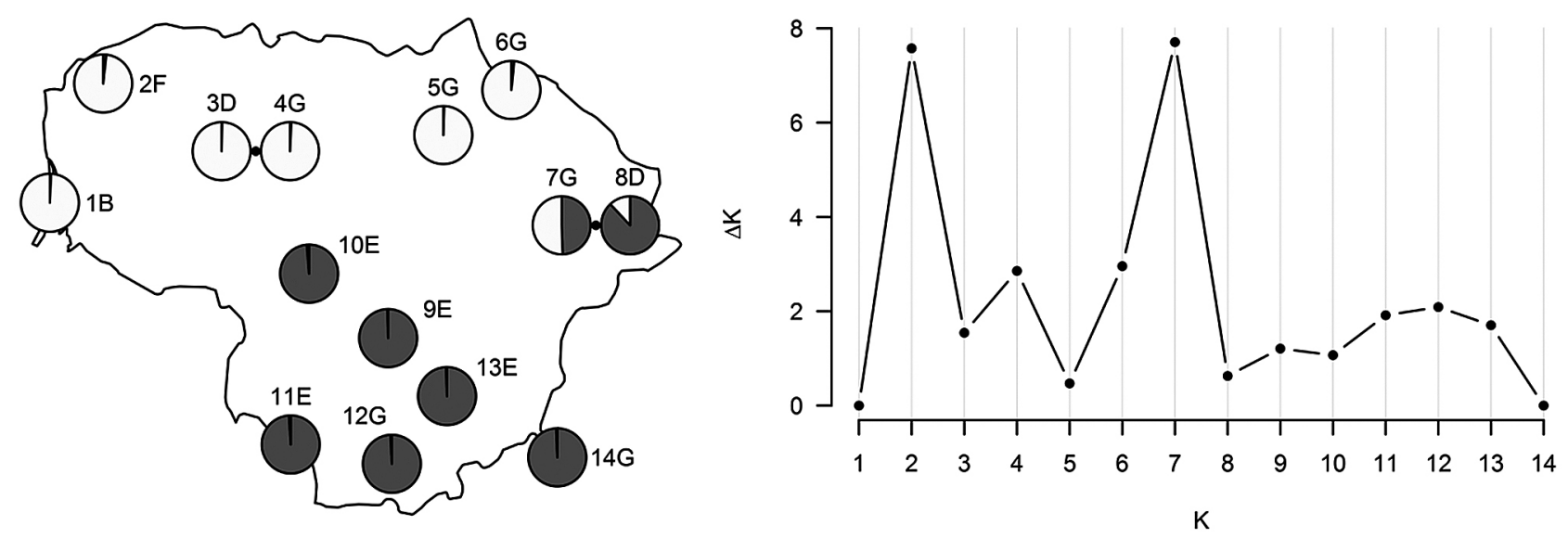

Fig. 4. Location of Lithuanian populations (full names of populations are provided in Table 1) of J. communis L. with the data of Bayesian analyses. Left, Bayesian clustering plots of populations in the map; a pie diagram indicates the proportion of membership of each predefined $K=2$ clusters (i.e. 2 different gene pools labeled in black and white colors) with the next to the highest $\Delta K$ (see Materials and methods) in the populations; right, $\Delta K$ values for $K$ ranging between 1 and 14

Table 4. ISSR data based molecular variance of J. communis: within and among populations, among groups of populations classified according to geography: northern (NLT: 1 B, 2 F, 3 D, 4 G, 5 G, 6 G, 7 G, 8 D) and southern Lithuania (SLT: 9 E, 10 E, 11 E, 12 G, 13 E, 14 G)

\begin{tabular}{lrrccc}
\hline \multicolumn{1}{c}{ Level of variation } & \multicolumn{1}{c}{ df } & \multicolumn{1}{c}{ SS } & Variance components & Percentage of variation & Significance (p) of differences \\
\hline Among NLT and SLT & 1 & 525 & 3.70 & 6.15 & $<0.002$ \\
Among populations within regions & 12 & 3250 & 23.81 & 39.54 & $<0.001$ \\
Within populations & 126 & 4121 & 32.71 & 54.31 & $<0.001$ \\
Total & 139 & 7895 & 60.22 & 100.00 & \\
\hline
\end{tabular}

senting all distinct habitats, b) 2 groups, separating populations of subcontinental moss Scots pine forest as prevailing habitat from populations representing all other 4 types of habitats. For these cases hierarchic molecular variance between the groups was not significant (these data are not provided in the table).

\section{Discussion}

Significant part of Juniperus surveys is devoted to relate DNA polymorphism and essential oils (Adams, 2011; Filipowicz et al., 2006). Influence of external factors on genetic diversity of the junipers including geographical proximity (Oostermeijer \& Knegt, 2004; Sobierajska et al., 2016), long-term evolution (Hantemirova et al., 2012; Filipowicz et al., 2006; Meloni et al., 2006; Boratyński et al., 2014) has been shown in previous studies. However, there are only few studies where habitat-related peculiarities are mentioned: association between ISSR-related data and habitat type of populations have been described for J. brevifolia populations from the Azorean archipelago (Silva et al., 2011) and J. communis from Wales and England (Van der Merwe et al., 2000).

In previous dendrological or biochemical studies of Lithuanian junipers different habitat types have been analysed (Vaitkevičiūtė et al., 2011a; 2011b;
Labokas \& Loziene, 2013). Our present study confirmed habitat-related differences of populations according to the indicatory values of herbaceous species (Ellenberg et al., 1991), growing besides J. communis. Principal component analysis of Ellenberg indicatory values for each site, has subdivided populations into three clusters (Fig. 1): the $1^{\text {st }}$ cluster, comprising all populations of xero-thermophile fringes $(E)$, the $2^{\text {nd }}$ cluster, comprising populations of transition mires and quaking bogs (D) and the $3^{\text {rd }}$ cluster, inside which populations of subcontinental moss Scots pine forests $(G)$ were slightly separated from two other populations, one representing Juniperus communis shrubs (F) and the other population of coastal brown dunes covered with natural Scots pine forests (B).

South-Eastern part of Lithuania is the most densely covered area by junipers (Vaitkevičiūtè et al., 2011a) with prevailing subcontinental moss Scots pine forest (G) habitat type. The analysis of this single habitat type populations might have shown smaller values of polymorphic DNA, compared to the mean obtained for the all habitat type junipers. If selection of populations bypasses some habitats, this parameter of DNA could be underestimated or overestimated. In our study, polymorphism at ISSR loci differed 1.6 times depending on habitat of population, being the lowest for D and G habitats, intermediate - for 
$\mathrm{B}$ and $\mathrm{E}$ habitats and the highest for F habitat. Mean value of percentage of polymorphic DNA at ISSR loci per populations of J. communis of Lithuania (47.1\%), was similar to that, determined for populations of $J$. phoenica (45\%; Meloni et al., 2006) or lower when compared to J. brevifolia studies (67\%, Silva et al., 2011; 69.7\%, Bettencourt et al., 2015). Moderate percentage of polymorphic DNA of Lithuania populations of J. communis might be due to several reasons. Intensive road building and urbanization during former century has strongly fragmented habitats. As reported in other countries (Oostermeijer \& Knegt, 2004), such process had negative effect on density of junipers. Air pollution effects described for Picea and Pinus genera, demonstrate high sensitivity of conifers to air pollutants and ammonia in particular (Krupa, 2003). The increase in agriculture activities also contributed to segregation of former widespread species (Van der Merwe et al., 2000). Within 1950s-1980s intensive animal husbandry has been established in Lithuania (www.am.lt). Despite overtopped agriculture, the effects of animal husbandry on junipers and other conifers has not been investigated; however, many woodmen consider it as one of the major reasons of juniper decline in some parts of Lithuania. It is worth pointing out that expressed genetic drift in sparse populations might influence interpopulation genetic diversity (Van der Merwe et al., 2000). Restricted gene flow $\left(N_{\mathrm{m}}=0.518\right)$ of junipers that was documented in our study might be related to highly fragmented habitats in our country.

Level of between population variability (AMOVA analysis) at ISSR loci of J. communis (44.1\%) in Lithuania was moderate. It is in agreement to $45 \%$ among population variability documented for endemic populations of J. brevifolia from the Azorean archipelago (Silva et al., 2011), where different habitat populations were compared (lowland coastal populations displayed a significantly higher diversity than the mountain populations). In the surveys where habitat types were not mentioned for selected sites, interpopulation variability at ISSR loci for populations was lower: for J. phoenica - 12\% (Meloni et al., 2006) and for J. brevifolia 7\% (Bettencourt et al., 2015). Direct comparison of separate studies is difficult due to numerous factors, influencing genetic diversity (species breeding system, geographical range, etc.; Sanchez-Gomez et al., 2013). Distinct ISSR primer sets applied in different investigations might also be one of the reasons in result bias: all seven primers used for J. brevifolia by Silva et al. (2011) were the same as in our examination, while only three primers corresponded to the ones used in J. brevifolia survey (Bettencourt et al., 2015). Both (RAPD and ISSR) dominant markers showed rich allelic diversity in $J$. brevifolia accessions and a moderate genetic similarity (Lima et al., 2010). According to isoenzyme anal- ysis of 35 populations of J. communis L. from Russia, only $12 \%$ interpopulation variability was observed in case of all chosen loci (10), at the same time, for separate two loci, 6-Pgdh-B and Fdh, 23 and $30 \%$ of genetic variability were distributed between populations (Hantemirova et al., 2012). For J. phoenicea the level of genetic differentiation according to 17 isoenzyme loci was high, indicating about $43 \%$ of the genetic variation between populations (Boratyński et al., 2009).

Principal coordinate analyses at ISSR loci (Fig. 3) clearly separated populations according to the geographic location: more northern part of Lithuania (eight populations) and more southern part of the country (six populations). The bigger the geographic distance between populations, the greater differences might be expected in terms of climate and/or edaphic factors. For Lithuanian populations of J. communis Mantel test showed significant moderate correlation between geographic and ISSR-based genetic distances and all individuals were correctly allocated to their populations by cluster analysis. ISSR data of J. brevifolia showed no statistically significant genetic structure by geographic distance (Bettencourt et al., 2015), while low correlations were detected comparing ISSR and geography variables for the other conifer genera (Sanchez-Gomez et al., 2013).

According to the set of climate parameters (sum of $\mathrm{T}^{\circ}$ in summer, when day $\mathrm{T}^{\circ}$ is higher than $10^{\circ}$; mean of absolute minimum $\mathrm{T}^{\circ}$; annual rainfall $\mathrm{mm}$; snow coverage in days; sum of days without frosts) Lithuania is subdivided into four climatic regions, with evident West-East and North-South differences. Hierarchic AMOVA and Bayessian Structure analysis show that molecular variance of populations of J. communis at ISSR loci might be associated with the climate of Lithuania. AMOVA showed small, although significant differences $(6.2 \%$ of molecular variation; Table 4) between populations of J. communis, subdivided into northern (1 B, 2 F, 3 D, 4 G, 5 G, $6 \mathrm{G}, 7 \mathrm{G}, 8 \mathrm{D})$ and southern (9 E, $10 \mathrm{E}, 11 \mathrm{E}, 12 \mathrm{G}$, 13 E, 14 G) parts of Lithuania. Principal coordinate and Bayessian analyses of ISSR data also supported geography related differences of J. communis populations. Our data are in agreement with phenological differences between northern and southern parts of Lithuania observed for other species (Romanovskaja et al., 2009). Genetic differences of juniper populations in northern and southern Lithuania might be partially related to different habitat sets in these parts of the country. In other studies, accessions of J. brevifolia (Lima et al., 2010) were also grouped according to their geographical origin. Both geographical and habitat elements might be underpinned in the studies of genetic diversity: edaphic, climatic and some other factors might affect genetic diversity of juniper populations of highland zone in Wales and 
chalk hills in South England located far away (Van der Merwe et al., 2000).

Two sets of geographically coupled (growing in $0.5 \mathrm{~km}$ distance) populations (3 $\mathrm{D}$ and $4 \mathrm{G}$, also 7 $\mathrm{G}$ and $8 \mathrm{D}$ ) occurring in different parts of Lithuania were chosen to evaluate the influence of edaphic environment on molecular variance. According to the appearance of junipers and polymorphic DNA percentage, subcontinental moss Scots pine forest was a more favorable habitat compared to transition mires and quaking bogs. In the UPGMA based dendrogram, all individuals from the paired populations have been correctly separated into different clades (Fig. 2). It was true in case of both selected pairs of habitats. These data point out that edaphic factors, like soil humidity, acidity and nitrogen in long-term survival of population might be related to ISSR loci. In addition, pollen and seed dispersal might be different due to different morphology and composition of neighboring species. A Dutch study suggested to separate juniper seeds collected in heathland and calcareous grassland populations, because the substrate was very different (Oostermeijer \& Knegt, 2004).

In the ISSRs based dendrogram (Fig. 2) the most distinct population in Lithuania was Juniperus communis shrubs representing the area protected by EUNIS (2 F; Davies et al., 2004; EEA, 2015). According to principal coordinate analysis populations of $E$ habitat type differed from populations of the other (B, F, D) habitat types, but not $G$ type. Previous studies have also shown that differences in genetic diversity $(h)$ between populations were significant only for populations representing the most contrasting habitats: the lowland coastal populations displayed a significantly higher diversity than the mountain populations, while forest and pioneer shrub populations did not differ from both above mentioned populations (Silva et al., 2011).

Recent ongoing severe climate fluctuations create new unfavorable survival scenarios for weaker individuals of the species (Verheyen et al., 2009). Comparison of 42 populations of J. communis across Western Europe showed negative correlation between vitality of the seeds and mean temperature of vegetation season. Despite more northern location of Lithuania in the continent, heat extremes in July, 2014 as well as two severe drought episodes in the summer of 2015 were registered in the country (www.meteo. lt).

Anthropogenic pressure on the areas of valuable landscapes is growing. Infrastructure for rural tourism is extensively being developed. Because of that, clear conservation strategies of forest management should be developed taking into account genetic peculiarities of existing habitat variety of junipers. Our data on J. communis populations from Lithuania adds valuable insights into the puzzle of genetic structure at ISSR loci in eastern-northern parts of Europe. These findings might also be a valuable source of information for the future breeding practice in Baltic States. We acknowledge, that other insights into genetic structure of populations from different habitats and extension of the study employing co-dominant molecular markers together with physiological and biochemical profiles is required in the nearest future. The selection of J. communis populations for our study was based only on variety of habitats and frequency of their distribution in rather small territory of Lithuania. Therefore, there is a need for large-scale observational studies covering a broader range of different habitats across Europe.

In conclusion, our study shows that molecular variance between populations of J. communis in Lithuania at ISSR loci might be related to habitat type. For evaluation and preservation of diversity of J. communis, different assessment methods should be included and management strategies should be directed in the way to retain variety of habitats encompassing both widely spread and less common ones.

\section{Acknowledgements}

We are grateful for people who suggested sampling sites or technically participated in the research: dr. K. Loziene (Nature Research Center, Vilnius); E. Podzarova and A. Vilkaityte (Vytautas Magnus University); woodwards C. Mikulskas (Kalvarija), S. Gliaudys (Vainagiai) and A. Rinkevicius (Pandelis) of Forest State enterprise. We also thank dr. J. Kupcinskas for corrections of the English language.

\section{References}

Adams RP (2011) Junipers of the World: The Genus Juniperus. $3^{\text {rd }}$ ed. Trafford Publishing Company, Victoria, BC.

Adams RP \& Demeke T (1993) Systematic relationships in Juniperus based on random amplified polymorphic DNAs (RAPDs). Taxon 42: 553-571. doi: 10.2307/1222534.

Adams RP, Schwarzbach AE \& Pandey RN (2003) The concordance of terpenoid, ISSR and RAPD markers, and ITS sequence data sets among genotypes: an example from Juniperus. Biochemical Systematics and Ecology 31: 375-387. doi: 10.1016/ S0305-1978(03)00036-X.

Androsiuk P \& Urbaniak L (2014) Genetic variability of Pinus sylvestris populations from IUFRO 1982 provenance trial. Dendrobiology 71: 23-33. doi: org/10.12657/denbio.071.003.

Areskeviciene R, Zvingila D, Gabrilavicius R \& Kuusiene S (2005) The estimation of genetic diversity within and between Lithuanian popula- 
tions of Norway spruce (Picea abies (L.) Karst.) by using RAPD. Baltic Forestry 11: 2-8.

Bettencourt SX, Mendonca D, Lopes MS, Rocha S, Monjardino P, Monteiro L \& Da Camara Machado A (2015) Genetic diversity and population structure of the endemic Azorean juniper, Juniperus brevifolia (Seub.) Antoine, inferred from SSRs and ISSR markers. Biochemical Systematics and Ecology 59: 314-324. doi:org/10.1016/j. bse.2015.02.003.

Boratyński A, Lewandowski A, Boratyńska K, Montserrat JM \& Romo A (2009) High level of genetic differentiation of Juniperus phoenicea (Cupressaceae) in the mediterranean region: geographic implications. Plant Systematics and Evolution 277: 163-172. doi: 10.1007/ s00606-008-0122-z.

Boratyński A, Wachowiak W, Dering M, Boratyńska K, Sękiewicz K, Sobierajska K, Jasińska AK, Klimko M., Montserrat JM, Romo A, Ok T \& Didukh Y (2014) The biogeography and genetic relationships of Juniperus oxycedrus and related taxa from the Mediterranean and Macaronesian regions. Botanical Journal of the Linnean Society 174: 637653. doi: 10.1111/boj.12147.

Butkiene R, Nivinskiene O \& Mockute D (2006) Differences in the essential oils of the leaves (needles), unripe and ripe berries of Juniperus communis L. growing wild in Vilnius district (Lithuania). Journal of Essential Oil Research 18: 489-494. doi: 10.1080/10412905.2006.9699150.

Davies CE, Moss D \& Hill MO (2004) EUNIS Habitat Classification revised 2004. European Topic Centre on Nature Protection and Biodiversity, Paris.

Douaihy B, Vendramin GG, Boratyński A, Machon N \& Bou Dagher-Kharrat M (2011) High genetic diversity with moderate differentiation in Juniperus excelsa from Lebanon and the eastern Mediterranean region. AoB PLANTS plr003. doi:10.1093/ aobpla/plr003.

Doyle JJ \& Doyle JL (1990) Isolation of plant DNA from fresh tissue. Focus 12: 13-15.

Dzialuk A, Mazur M, Boratynska K, Montserrat JM, Romo A \& Boratyński A (2011) Population genetic structure of Juniperus phoenicea (Cupressaceae) in the western Mediterranean Basin: gradient of diversity on a broad geographical scale. Annals of Forest Science 68: 1341-1350. doi: 10.1007/ s13595-011-0150-7.

EEA (2015) The European Environment. State and Outlook 2015. Synthesis report. doi:10.2800/944899.

Ellenberg H, Weber HE, Düll R, Wirth V, Werner W \& Paulißen D (1991) Zeigerwerte von Pflanzen in Mitteleuropa. Scripta Geobotanica 18: 1-258.

Evanno G, Regnaut S \& Goudet J (2005) Detecting the number of clusters of individuals using the software STRUCTURE: a simulation study. Molecular Ecology 14: 2611-2620.

Excoffier L \& Lischer HEL (2010) Arlequin suite ver. 3.5: A new series of programs to perform population genetics analyses under Linux and Windows. Molecular Ecology Resources 10: 564-567.

Falush D, Stephens M \& Pritchard JK (2003) Inference of population structure using multilocus genotype data: Linked loci and correlated allele frequencies. Genetics 164: 1567-1587.

Filipowicz N, Piotrowski A, Ochocka JR \& Asztemborska M (2006) The phytochemical and genetic survey of common and dwarf juniper (Juniperus communis and Juniperus nana) Identifies chemical races and close taxonomic identity of the species. Planta Medica 72: 850-853. doi: 10.1055/s-2006941543.

Gruwez R, Leroux O, De Frenne P, Tack W, Viane R \& Verheyen K (2013) Critical phases in the seed development of common juniper (Juniperus communis). Plant Biology 15: 210-219. doi: 10.1111/j.1438-8677.2012.00628.x.

Hantemirova EV, Berkutenko AN \& Semerikov VL (2012) Systematics and gene geography of Juniperus communis inferred from isoenzyme data. Russian Journal of Genetics 48: 920-926. doi: 10.1134/S1022795412090050.

Jongman RHG, Ter Braak CJF \& Van Tongeren OFR (1995) Data analysis in community and landscape ecology. Cambridge, University Press, New York.

Kasaian J, Behravan J, Hassany M, Emami SA, Shahriari F \& Khayyat MH (2011) Molecular characterization and RAPD analysis of Juniperus species from Iran. Genetics and Molecular Research 10: 1069-1074. doi: 10.4238/vol10-2gmr1021.

Krupa SV (2003) Effects of atmospheric ammonia $\left(\mathrm{NH}_{3}\right)$ on terrestrial vegetation: a review. Environmental Pollution 124: 179-221. doi: 10.1016/ S0269-7491(02)00434-7.

Labokas J \& Loziene K (2013) Variation of essential oil yield and relative amounts of enantiomers of $\alpha$-pinene in leaves and unripe cones of Juniperus communis L. growing wild in Lithuania. Journal of Essential Oil Research 25: 244-250. doi: 10.1080/ 10412905.2013.775678.

Lima AS, Trindade H, Figueiredo AC, Barroso JG \& Pedro LG (2010) Volatile and molecular analysis of Juniperus brevifolia (Seub.) Antoine, an Azorean endemic species. Biochemical Systematics and Ecology 38: 621-629. doi: 10.1016/j. bse.2010.07.010.

Lithuanian Hydrometeorological Service under the Ministry of Environment. http://www.meteo.lt/ en/web/guest/climate-regions-of-lithuania.

Marozas V, Racinskas J \& Bartkevicius E (2007) Dynamics of ground vegetation after surface fires in hemiboreal Pinus sylvestris forests. Forest Ecology 
and Management 250:47-55. doi: 10.1016/j.foreco.2007.03.008.

Meloni M, Perini D, Filigheddu R \& Binelli G (2006) Genetic variation in five Mediterranean populations of Juniperus phoenicea as revealed by Inter-simple sequence repeat (ISSR) markers. Annals of Botany 97: 299-304. doi: 10.1093/aob/ mcj024.

Michalczyk IM, Sebastiani F, Buonamici A, Cremer E, Mengel C, Ziegenhagen B \& Vendramin GG (2006) Characterization of highly polymorphic nuclear microsatellite loci in Juniperus communis L. Molecular Ecology Notes 6: 346-348. doi: 10.1111/j.1471-8286.2005.01227.x.

Ministry of Environment of the Republic of Lithuania http://www.am.lt/VI/article.php3?article $\mathrm{id}=14510$.

Nei M (1978) Estimation of average heterozygosity and genetic distance from a small number of individuals. Genetics 89: 583-590.

Oostermeijer JGB \& De Knegt B (2004) Genetic population structure of the wind-pollinated, dioecious shrub Juniperus communis in fragmented Dutch heathlands. Plant Species Biology 19: 175184. doi: 10.1111/j.1442-1984.2004.00113.x.

Peakall R \& Smouse P (2012) GenAlEx v. 6.5: Genetic Analysis in Excel. Population genetic software for teaching and research - an update. Bioinformatics 28: 2537-2539. doi: 10.1093/bioinformatics/bts 460 .

Pritchard JK, Stephens M \& Donnelly P (2000) Inference of population structure using multilocus genotype data. Genetics 155: 945-959.

Provan J, Beatty GE, Hunter AM, McDonald RA, McLaughlin E, Preston SJ \& Wilson S (2008) Restricted gene flow in fragmented population of a wind-pollinated tree. Conservation Genetics 9: 1521-1532. doi:10.1007/s10592-007-9484-y.

Romanovskaja D, Kalvane G, Briede A \& Baksiene E (2009) The influence of climate warming on the changes of the length of phenological seasons in Lithuania and Latvia. Zemdirbyste-Agriculture 96: 218-231.

Rumeu B, Caujape-Castells J, Blanco-Pastor JL, Jaen-Molina R, Nogales M, Elias RB \& Vargas $P$ (2011) The colonization history of Juniperus brevifolia (Cupressaceae) in the Azores Islands. PLoS ONE 6: e27697. doi:10.1371/journal. pone.0027697.

Sanchez-Gomez P, Jimenez JF, Vera JB, Sanchez-Saorin FJ, Martinez JF \& Buhagiar J (2013) Genetic structure of Tetraclinis articulata, an endangered conifer of the western Mediterranean basin. Silva Fennica 47: 1-14. doi.org/10.14214/sf.1073.

Silva L, Elias RB, Moura M, Meimberg H \& Dias E (2011) Genetic variability and differentiation among populations of the Azorean endemic gym- nosperm Juniperus brevifolia: baseline information for a conservation and restoration perspective. Biochemical Genetics 49: 715-734. doi: 10.1007/ s10528-011-9445-5.

Sobierajska K, Boratyńska K, Jasińska AK, Dering M, Ok T, Douaihy B, Bou Dagher-Kharrat M, Romo A \& Boratyński A (2016) Effect of the Aegean Sea barrier between Europe and Asia on differentiation in Juniperus drupacea (Cupressaceae). Botanical Journal of the Linnean Society 180: 365-385. doi: 10.1111/boj.12377.

Thomas PA, El-Barghathi M \& Polwart A (2007) Biological Flora of British Isles: Juniperus communis L. Journal of Ecology 95: 1404-1440. doi: 10.1111/j.1365-2745.2007.01308.x.

Vaitkevičiūtè R, Brazaitis G, Šepetienè J \& Žalkauskas R (2011a) Cross valuation of juniper formation recreational and ecological viewpoints: Rural Development 2011: the $5^{\text {th }}$ International Scientific Conference. Aleksandras Stulginskis University, Akademija, Lithuania, pp. 156-160.

Vaitkevičiūtė R, Brazaitis G \& Šepetienė J (2011b) Dendrological and recreational values of $\mathrm{Ar}$ laviškès juniper formation. Acta Biologica Universitatis Daugavpiliensis 11: 126-133.

Van De Peer Y \& De Wachter R (1994) TREECON for Windows: a software package for the construction and drawing of evolutionary trees for the Microsoft Windows environment. Computer Applications in Biosciences 10: 569-570.

Van der Merwe M, Winfield MO, Arnold GM \& Parker JS (2000) Spatial and temporal aspects of the genetic structure of Juniperus communis populations. Molecular Ecology 9: 379-386. doi: 10.1046/j.1365-294x.2000.00868.x

Verheyen K, Adriaenssens S, Gruwez R, Michalczyk IM, Ward LK, Rosseel Y, Van den Broeck A \& Garcia D (2009) Juniperus communis: victim of the combined action of climate warming and nitrogen deposition? Plant Biology 11: 49-59. doi: 10.1111/j.1438-8677.2009.00214.x.

Ward LK (1982) The conservation of Juniper: longevity and old age. Journal of Applied Ecology 19: 917-928. doi: 10.2307/2403293.

Yeh FC, Yang R \& Boyle TJB (1999) Popgene Version 1.31. Microsoft Window-based freeware for population genetic analysis. Centre for International Forestry Research. University of Alberta, pp. $1-28$.

Zvingila D, Verbylaite R, Abraitis R, Kuusiene S \& Ozolincius R (2002) Assessment of genetic diversity in plus tree clones of Pinus sylvestris L. using RAPD markers. Baltic Forestry 8: 2-7. 